\title{
Soybean Resistance to Soybean Mosaic Virus
}

\author{
Kristin Widyasari ${ }^{1}\left(\mathbb{D}\right.$, Mazen Alazem ${ }^{1,2}$ and Kook-Hyung Kim ${ }^{1,2,3, *(\mathbb{C})}$ \\ 1 Department of Agricultural Biotechnology, College of Agriculture and Life Sciences, \\ Seoul National University, Seoul 08826, Korea; kristin@snu.ac.kr \\ 2 Plant Genomics and Breeding Institute, College of Agriculture and Life Sciences, Seoul National University, \\ Seoul 08826, Korea; m.alazem@snu.ac.kr \\ 3 Research Institute of Agriculture and Life Sciences, College of Agriculture and Life Sciences, \\ Seoul National University, Seoul 08826, Korea \\ * Correspondence: kookkim@snu.ac.kr; Tel.: +82-2-880-4677
}

Received: 2 January 2020; Accepted: 6 February 2020; Published: 8 February 2020

check for updates

\begin{abstract}
Soybean mosaic virus (SMV) occurs in all soybean-growing areas in the world and causes huge losses in soybean yields and seed quality. During early viral infection, molecular interactions between SMV effector proteins and the soybean resistance $(\mathrm{R})$ protein, if present, determine the development of resistance/disease in soybean plants. Depending on the interacting strain and cultivar, R-protein in resistant soybean perceives a specific SMV effector, which triggers either the extreme silent resistance or the typical resistance manifested by hypersensitive responses and induction of salicylic acid and reactive oxygen species. In this review, we consider the major advances that have been made in understanding the soybean-SMV arms race. We also focus on dissecting mechanisms SMV employs to establish infection and how soybean perceives and then responds to SMV attack. In addition, progress on soybean $R$-genes studies, as well as those addressing independent resistance genes, are also addressed.
\end{abstract}

Keywords: extreme resistance; $R$-gene resistance; soybean; soybean mosaic virus

\section{Introduction}

Soybean is an important food and fodder crop which is vulnerable to infection by many viruses, but only few exhibit economic importance on soybean production [1-3]. These economically important viruses include soybean mosaic virus (SMV), bean pod mottle virus (BPMV), soybean vein necrosis virus, tobacco ringspot virus, soybean dwarf virus, and alfalfa mosaic virus (AMV) [3]. Infection by multiple soybean viruses, such as SMV and BPMV or AMV, has also been reported to cause greater damage than infection by a single virus [4].

SMV, from the genus Potyvirus and the family Potiviridae, causes soybean mosaic disease, a disease that greatly reduces soybean production worldwide [1,5]. SMV has a very narrow host range which is limited to six plant families: Fabaceae, Amaranthaceae, Chenopodiaceae, Passifloraceae, Schrophulariaceae, and Solanaceae. The most commonly infected hosts are Glycine soja (wild soybean) and Glycine max (cultivated soybean) [3,6]. Management of SMV is limited to the use of good agricultural practices and the development of resistant cultivars via breeding and genetic engineering [7]. Several SMV strains, however, have evolved the ability to avoid recognition by the plant R-protein and to thereby establish infections which lead to the emergence of resistance breaking SMV strains [8,9]. Hence, improving the understanding of how soybean perceives and responds to SMV infection will help the development of molecular breeding towards broad-spectrum resistance against SMV.

Soybean and SMV interact in complex ways during each step of infection. SMV passively enters plant cells through natural openings or through physical wounds caused by environmental factors or insect vectors [10]. If the host is unable to recognize the SMV effector(s), a compatible interaction 
is established. The severity of the resulting disease depends on the ability of the virus to hijack host proteins and suppress immune responses [11].

According to the mode of interaction between plant and viruses, resistance is often classified into recessive resistance and dominant resistance. Recessive resistance is established upon the impairment of a host factor required for virus replication, or negatively involved in resistance [12]. In contrast, dominant resistance, which leads to incompatible interaction, is triggered upon the recognition of viral effector by the host resistance $(\mathrm{R})$ protein $[7,10]$. The incompatible interaction between soybean and SMV is characterized by the induction of salicylic acid (SA), the development of a hypersensitive response (HR), and a burst in the production of reactive oxygen species (ROS). These lead to the death of the infected cells and trap the virus at the point of infection [11,13-15]. SA is a hallmark in many incompatible interactions, including Rsv1-mediated resistance against the SMV-N avirulent strain $[13,16,17]$. Interestingly, abscisic acid (ABA), which antagonizes the SA effect, appears to play a critical role in the incompatible interaction between the resistance gene Rsv3 and the avirulent strain SMV-G5H $[18,19]$. Both SA and ABA have been reported to positively regulate plant resistance against several viruses [in both compatible and incompatible interactions], but some viruses are able to reverse the defensive effects of ABA [19-22].

It is well-known that plants have evolved defense mechanisms against viruses and other pathogens. Researchers have made substantial progress in understanding the ability of plants to defend against viral pathogens [23-25]. In soybean, three independent loci (Rsv1, Rsv3, and Rsv4) have been characterized to confer resistance against SMV strains G1-G7 [26,27] and other resistance loci (R-genes: Rsc4, Rsc5, $R s c 7, R s c 8, R s c 15$, and $R s c 20$ ) where characterized in China to confer resistance against SMV-SCs strains [28-33]. In this review, we highlight the diversity of mechanisms underlying the soybean defense response against SMV and especially the ability of $R$-genes and other genes to perceive SMV invasion.

\section{Biological Properties and Transmission of SMV}

\subsection{SMV Genome and Gene Function}

SMV has been grouped into seven strains (G1 to G7) based on its virulence to soybean lines cultivated in the United States [34], and into 22 strains (SC1 to SC22) based on the Chinese identification system [35,36]. The SMV genome consists of a single-stranded positive-sense RNA, which is approximately $10 \mathrm{~kb}$ long and associated with genome-linked viral protein (VPg) bound to the $5^{\prime}$ end and the poly (A) tail at the $3^{\prime}$ end of the viral genome. Both the RNA and VPg are encapsidated in rod-shaped coat protein $(\mathrm{CP})[6,37]$. The genome encodes one large open reading frame (ORF), which is translated into a large polyprotein and subsequently undergoes a proteolytic reaction yielding 10 different functional proteins. A frameshift in the P3 cistron, the SMV genome also produces a small ORF that encodes for the $11^{\text {th }}$ protein with a size of $25 \mathrm{kDa}$ [38]. These 11 proteins are P1, HC-Pro, $\mathrm{P} 3$, PIPO (a product of slippage in the P3 coding sequence), 6K1, CI, 6K2, VPg, NIa-Pro, NIb, and CP (Table 1) [38-40]. 
Table 1. Summary of the biological functions of SMV proteins.

\begin{tabular}{|c|c|c|}
\hline Protein & Function for Virus & Function for Plant \\
\hline P1 & Protease $[41,42]$, Viral host range $[43,44]$ & \\
\hline HC-Pro & $\begin{array}{c}\text { Long-distance movement [45], a 'bridge' between virion particles } \\
\text { and aphid stylets in aphid transmission [46,47], suppression of host } \\
\text { defense (RNA silencing) [48] }\end{array}$ & Virulence determinant $[49,50]$ \\
\hline P3 & $\begin{array}{l}\text { Targets host elongation factors } 1 \mathrm{~A}(\mathrm{eEF} 1 \mathrm{~A}) \\
\text { to facilitate SMV replication [51] }\end{array}$ & Effector of Rsv1 [50,52], Effector of Rsv4 [53] \\
\hline PIPO & Movement [54] & \\
\hline $6 \mathrm{~K} 1$ & Cell-to-cell movement [55] & \\
\hline $\mathrm{CI}$ & $\begin{array}{l}\text { Required for genome replication and movement } \\
\text { (cell-to-cell or long-distance movement) [56] }\end{array}$ & Effector of Rsv3 [57,58] \\
\hline $6 \mathrm{~K} 2$ & Formation of the virus replication complex $[59,60]$ & \\
\hline $\mathrm{VPg}$ & Binds specifically to eIF4E to initiate polyprotein translation $[61,62]$ & \\
\hline NIa-Pro & Proteinase $[63,64]$ & \\
\hline $\mathrm{Nib}$ & The catalytic subunit of RdRp [65-67] & \\
\hline $\mathrm{CP}$ & $\begin{array}{l}\text { A 'bridge' between virion particles and aphid stylets in aphid } \\
\text { transmission [47], cell-to-cell movement, virus assembly }[68,69]\end{array}$ & \\
\hline
\end{tabular}

\subsection{Biological and Molecular Properties of SMV Infection and Transmission}

SMV replicates in the cytoplasm in virus replication complexes (VRCs) which are associated with endoplasmic reticulum (ER) [60]. P3 recruits the host elongation factor 1A (eEF1A) to initiate an unfolded protein response (UPR), an adaptive response that involves the accumulation of unfolded proteins at the ER, which in turn facilitates SMV replication [51]. VPg protein binds with eIF4E to initiate translation of the polyprotein, which is subsequently cleaved by viral proteases to produce 11 distinct functional proteins $[6,61,70]$.

Systemic infection by most plant viruses, including SMV, comprises two processes: cell-to-cell movement through plasmodesmata (PDs) and long-distance trafficking through the vascular system. PDs are essential for the intracellular trafficking of molecules required for plant life, and plant viruses have evolved to manipulate this communication system to facilitate intercellular movement [71]. The SMV MP and CP+HC-Pro complex increases PD size exclusion limits to facilitate the movement of virions into neighboring cells [72,73]. In the case of turnip mosaic virus, movement is also assisted by the PIPO protein which directs the CI protein to the PD where it forms a PIPO-CI complex [74]. This complex coordinates the formation of a PD-associated structure and facilitates the intercellular movement of the virion in the infected plants [74,75]. In addition, the $6 \mathrm{~K} 1$ protein localizes to the cell periphery, where it is thought to have an essential function in cell-to-cell movement [55]. The viral genome is transported from the epidermal to mesophyll cells through PDs. Once the viral genome reaches the vascular bundles, long-distance trafficking of the virus is initiated (Figure 1).

SMV is a seed- and aphid-transmitted virus, and aphids uptake SMV in a non-persistent manner $[47,76]$. Aphid transmission depends on the interaction between HC-Pro and CP proteins. The presence of a DAG sequence in the CP facilitates the transient binding of the CP to HC-pro and is essential for the binding of virus particles to the aphid stylet and thus for aphid transmission $[47,77]$. 


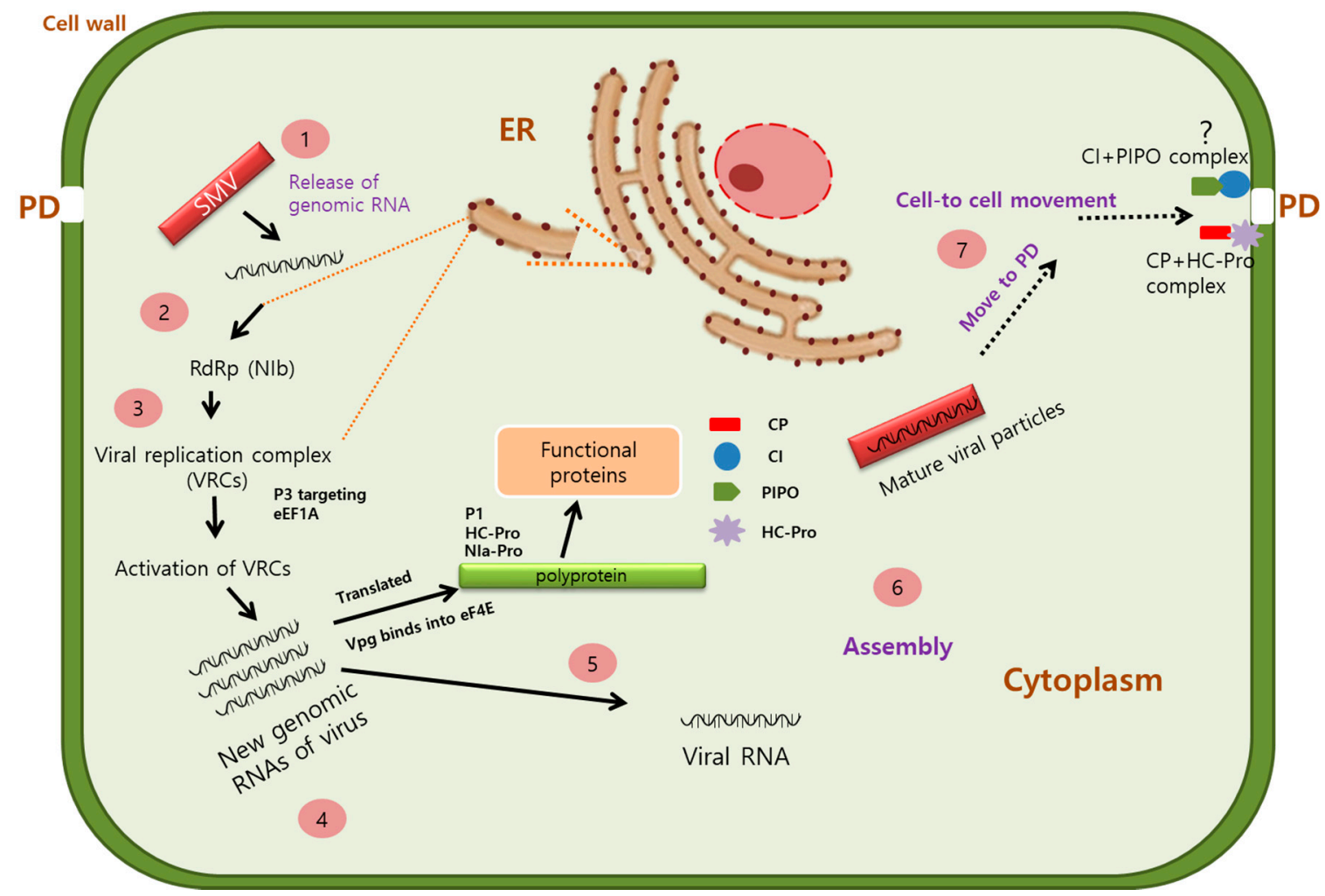

Figure 1. Replication and movement of soybean mosaic virus (SMV) within the cell. SMV enters the plant cell through natural openings such as the plasmodesmata (PD) or openings on the plant surface resulting from mechanical injury. Upon SMV entry, the viral genomic RNA is released and translated. Following translation of the viral proteins, virus particles assemble, and the new virus progeny move to neighboring cells. Virus movement is assisted by several functional proteins. The coat protein (CP) protects the genomic RNA, prevents degradation of viruses or virus components by host factors, and delivers the genomic RNA to PD. At PD, the proteins CI and PIPO form a CI-PIPO complex to coordinate the formation of the $\mathrm{PD}$-associated structure which facilitates the intracellular movement of the virus.

\section{Resistance Genes (R-Genes): Soybean Response to SMV Infection}

\subsection{NLR Gene Family-Mediated Resistance to SMV}

Host resistance proteins with nucleotide-binding (NB) domains and leucine-rich repeats (LRR), shortly termed as (NLRs), represent a major class of plant immune receptors that greatly affect host-pathogen interactions [78,79]. Upon perception of pathogen effectors, NLRs trigger a cascade of downstream defense events leading to the induction of resistance against the invading viruses [80]. NLRs may represent the evolution of multifunctional single receptors, which combine sensor activity (helper) and immune signaling (executor) in a single protein, into networks of functionally interconnected receptor pairs [81]. During the perception phase, NLRs sense viral effectors, directly or indirectly, and trigger an HR in the host [81]. Most R-proteins have NLR domains located in their N-termini. NLRs are divided into two subfamilies: one with a Toll/interleukin-1 receptor (TIR) domain and the other with a coiled-coil (CC) structure [82]. TIR motifs of R-proteins are often found in dicotyledonous plants [83,84]. A comprehensive study of NLR-type R-genes led to the identification and characterization of two groups of dominant R-genes in soybean which confer resistance against SMV: 1) Rsv genes which confer resistance to strains G1 to G7 in the United States [85,86] and 2) Rsc genes which confer resistance to SMV strains SC1 to SC22 in China $[35,36,87,88]$. 


\subsection{Rsv Genes}

Rsv1, Rsv3, Rsv4, and Rsv5 are four loci that confer resistance to different SMV strains. Rsv1 is a highly complex locus with multiple alleles mapped to molecular linkage group (MLG) F. The dominant Rsv1 locus is mapped to chromosome 13, and encoded candidate genes in the cultivar PI 96983 were identified as a cluster of nucleotide-binding leucine-rich repeat (NB-LRR)-type of $R$-genes [89]. Rsv1 confers resistance to SMV strains G1 to G6 but not to G7 [90]. Phenotypes of Rsv1-mediated resistance against SMV strains are diverse and include extreme resistance (ER) against SMV strains G1 to G6, lethal hypersensitive response (LSHR) against SMV-G7 [52], and HR occurring on the stem, petioles, and leaf veins of plants inoculated with G2 [15].

Rsv1-mediated ER against most SMV strains requires multiple defense genes, including those involved in the SA and JA pathways, and may also involve specific WRKY transcription factors [17,91]. Silencing soybean orthologs of the SA-related genes GmEDR1, GmEDS1, and GmPAD4, and the JA-related gene GmJAR1, in the SMV-resistant soybean line L78-379, resulted in symptoms that were similar to those recorded in the susceptible control cultivar (Williams 82) in response to infection with SMV-G2 [17]. In another study, double silencing of GmEDS1a/GmEDS1b or single silencing of GmPAD4 reduced pathogen-inducible SA accumulation, which further enhanced soybean susceptibility to SMV-G5 and thereby indicated the importance of SA in Rsv1-resistance against SMV-G5 [91]. In addition, silencing GmHSP90 severely stunted plants and reduced the replication and movement of SMV-G2 [17]. This suggests that the chaperone HSP90 is required for Rsv1-mediated ER in response to G2, an avirulent strain of SMV [6].

Many WRKY transcription factors regulate the transcriptional reprogramming associated with plant immune responses and plant development [92,93]. Several reports suggest that SA-related WRKYs are actively involved in Rsv1-mediated resistance against SMV-G2. For example, silencing the SA-induced WRKY6 and WRKY30 in the soybean line L78-379 compromised the Rsv1-mediated resistance against SMV-G2 in soybean line [17,94,95].

The P3 protein is the effector of Rsv1-mediated resistance, and the amino acids 823, 953, and 1112 are important for Rsv1 perception of P3 and thus for the subsequent induction of LSHR (Figure 2) [14,52]. Replacement of HC-Pro and/or P3 from avirulent strains with HC-Pro and/or P3 from virulent strains (SMV-G7 or SMV-G7d) changed the avirulent strains into virulent strains [49], suggesting that HC-Pro is also an effector for Rsv1-mediated resistance.

Rsv3 is mapped to a locus between the markers A519F/R and M3Satt on chromosome 14 in the soybean molecular linkage group B2 [96]. Further investigation revealed that the Rsv3 locus contains a family of closely related proteins with a CC motif and an LRR domain (CC-NB-LRR), suggesting that Rsv3 encodes a member of the NLR family $[96,97]$. Unlike Rsv1, which confers resistance to a broad spectrum of SMV strains, Rsv3 is a strain-specific resistant gene that confers ER only to SMV strains G5, G6, G7, and G5H [97] [57,98,99]. However, Rsv3 induces necrosis and mosaic symptoms depending on the infecting strain (G1 to G4), and induces systemic mosaic symptoms upon the infection with G7H [57]. Analyses of chimeras that were constructed by exchanging fragments between the avirulent SMV-G7 and the virulent SMV-N strains showed that both the $\mathrm{N}$ and $\mathrm{C}$ terminal regions of the CI cistron are required for Rsv3-mediated ER [58]. In a different study, a single amino acid substitution in the $\mathrm{CI}$ region between $\mathrm{G} 7 \mathrm{H}$ and $\mathrm{G} 5 \mathrm{H}$ abolished ER induction in response to the chimeric $\mathrm{G} 5 \mathrm{H}$ infection [57] (Figure 2).

The molecular signaling involved in the Rsv3-mediated ER was elucidated using the Rsv3-harbouring L29 plants. Infection with G5H allows Rsv3 to recognize the CI protein, which induces several genes in the ABA pathway, including the negative regulator PP2C3a $[18,100]$. Expression of $P P 2 C 3 a$ induces callous accumulation and thus restricts G5H movement at the infected points [100]. Analysis of RNA sequencing data also suggested that the Rsv3-mediated ER against SMV-G5H involves the antiviral RNA silencing pathway and autophagy. In addition, reduction in the expression of many genes in the jasmonic acid pathway and WRKY transcription factors were also observed following G5H infection on L29 plants. Interestingly, ABA can also induce resistance L29 plants against the 
G7H virulent strain by enhancing callous accumulation and increasing the expression of several genes involved in the antiviral RNA silencing pathway $[18,19]$. Future research addressing the localization of Rsv3, factors associated with Rsv3, and downstream defense signaling pathways would help us better understand the molecular mechanisms underlying Rsv3-mediated resistance.

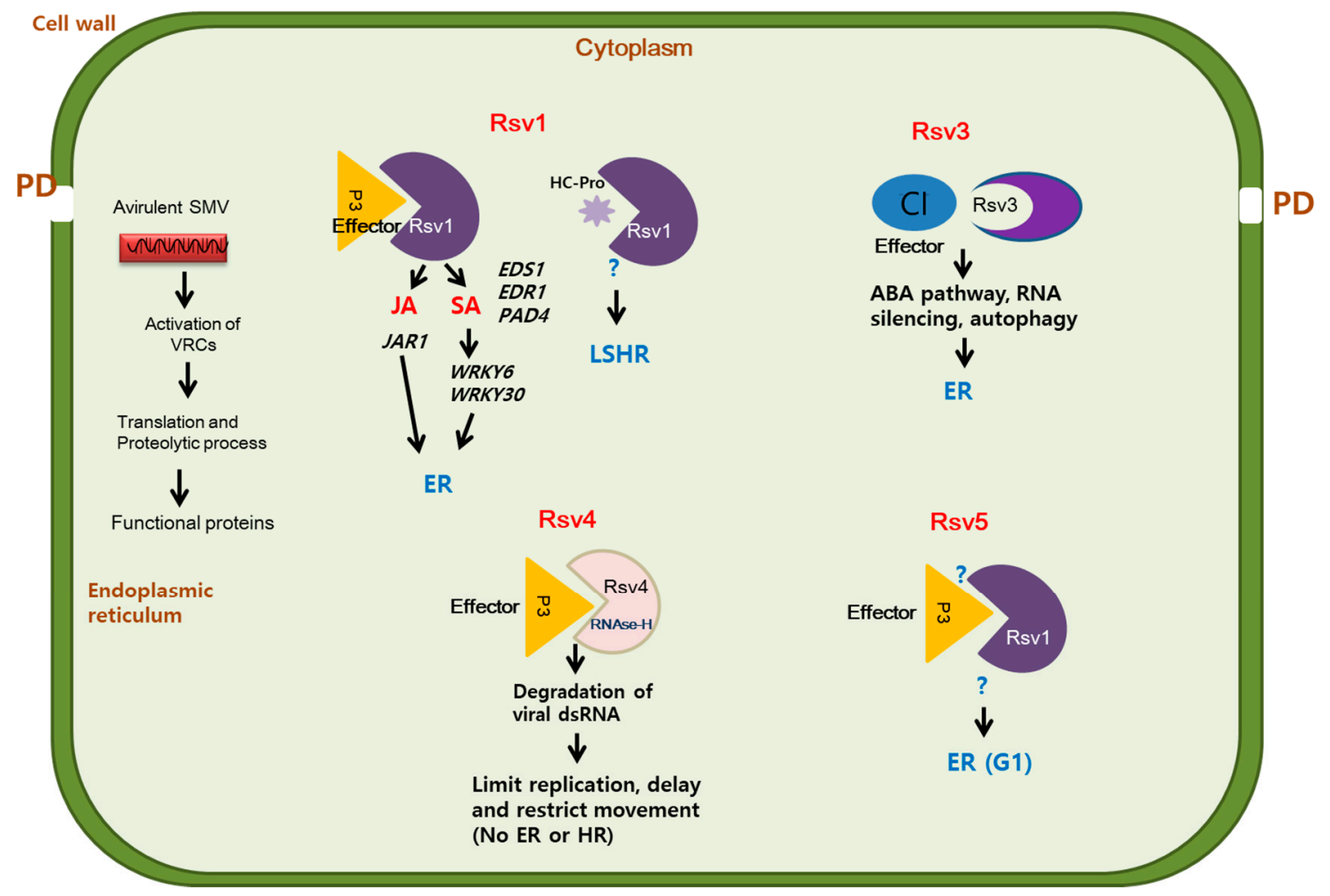

Figure 2. Rsv-mediated perception and resistance against SMV. Rsv1 recognizes the effectors P3 and/or HC-Pro protein; recognition of HC-Pro induces a lethal systemic hypersensitive response (LSHR), and recognition of P3 induces several host factors including HSP90, EDS1, EDR1, WRKY6, and WRKY30, which contribute in extreme resistance (ER) through the salicylic acid (SA) and jasmonic acid pathways. Rsv3 recognizes the CI protein and thereby induces ER where abscisic acid (ABA), and antiviral RNA silencing pathway and autophagy are triggered following infection. Rsv4 recognizes P3, which encodes dsRNAase, and targets the viral dsRNA in the replication complex leading to its degradation. The effector for Rsv5 is unknown, but the recognition results in ER in response to SMV-G1.

The Rsv4 locus is flanked by the microsatellite markers (SSRs) Satt542 (4.7 cM) and Satt558 (7.8 cM) [101]. Using whole genome sequencing of D26 (which carries the Rsv4 gene) crossed with Lee 68 (an rsv-null cultivar), and of V94-5152 (Rsv4) crossed with Lee 68 ( $r s v$ ), it has been determined that Rsv4 is localized in the $1.3 \mathrm{cM}$ region on chromosome 2 [102]. While this region does not encode any NLR gene, several genes encoding for transcription factors were located on that region [102]. Rsv4 confers resistance to strain G1 to G7 [103]. In G2 strain, a single amino acid substitution (Q1033K) in P3 protein enabled the mutant to overcome Rsv4 resistance in the soybean cultivar V94-5152 [53]. Sequence analysis of new variants of Rsv4-resistance-breaking isolates revealed that these isolates contained either the Q1033K mutation or a G1054R substitution in their P3 protein [53]. The combination of Q1033K and G1054R enhanced SMV movement and symptom severity in the soybean PI 88788 (Rsv4) [86]. These results suggest that SMV virulence determinants in Rsv4 cultivars are located on P3, and that Q1033K or G1054R substitution is sufficient to increase SMV virulence [53,86,104].

The strength of Rsv4-mediated resistance and the nature of the associated phenotypes differ between two cultivars carrying the Rsv4 gene (V94-5152 and PI 88788) [86,103]. While SMV-N accumulated in the inoculated leaves of both cultivars, infection was much less severe in V94-5152 than 
in PI 88788. These results indicate that Rsv4-mediated resistance is affected by the genetic background of the cultivar carrying the Rsv4 gene [86].

Given that Rsv4 does not encode NLR genes and that Rsv4-mediated resistance is quite different from Rsv1- or Rsv3- mediated resistance, it was proposed that Rsv4 belongs to a new class of resistance genes [102]. A recent study showed that Rsv4 encodes an RNase-H family protein with dsRNA-degrading activity and interacts with the P3 protein of SMV to promote the fusion of dsRNAses with host factors involved in virus replication. This fusion result in the degradation of the viral dsRNAs [65].

A study on the Rsv1 locus revealed that Rsv1 and Rsv1-y are separated by $2.2 \mathrm{cM}$ on chromosome 13 in the soybean cultivar York [105]. This substantial separation suggested renaming Rsv1-y, which confers resistance to G1 but not to G7, to become Rsv5 [106]. The cultivar York was developed from a cross between Dorman (developed from Dunfield and Arksoy) and Hood [106]. Similar to York, Dorman and Arksoy are resistant to G1 but not to G7, suggesting that Rsv1-y in York came from Arksoy [106]. Pedigree analysis of 18 other soybean genotypes derived from Arksoy showed that Riple, Calhoun, and Musen have Rsv1-y-mediated resistance [106]. The mechanism underlying Rsv1-y (or Rsv5)-mediated resistance remains unknown (Table 2).

Table 2. Summary of $R$ genes conditioning resistance to SMV.

\begin{tabular}{|c|c|c|c|c|c|}
\hline$R$ Gene & SMV Strain & Cultivar & Location & Effector & Type of $R$ Gene \\
\hline Rsv1 & G1-G6 [90] & $\begin{array}{c}\text { Kwanggyo } \\
\text { Marshall } \\
\text { Odgen } \\
\text { PI96983 } \\
\text { PI507389 } \\
\text { Raiden } \\
\text { Suweon97 } \\
\text { Kosuzu } \\
\text { Susumaru } \\
\text { PI39887 } \\
\text { Jitsuka } \\
\text { Clifford } \\
\text { Tousan65 } \\
\text { Corcisa } \\
\text { PI61944 } \\
\text { PI61947 [107,108] }\end{array}$ & Chromosome 13 & $\begin{array}{c}\text { P3 [14,52] } \\
\text { HC-pro [49] }\end{array}$ & NB-LRR-type of $R$-genes [89] \\
\hline Rsv3 & G5,G6,G7 [98,99] & $\begin{array}{c}\text { Columbia } \\
\text { Hardee } \\
\text { Tosan140 } \\
\text { PI } 339870 \\
\text { PI399091 } \\
\text { L29 }[90,108]\end{array}$ & Chromosome 14 & CI $[57,58]$ & CC-NB-LRR type or R-gene [96] \\
\hline Rsv4 & G1-G7 [103] & $\begin{array}{c}\text { PI486355 } \\
\text { V94-5152 } \\
\text { P188788 } \\
\text { Haman } \\
\text { Ilpumgeomjeong } \\
\text { KAERI-GNT-220-7 } \\
\text { PI } 398593 \\
\text { PI438307 } \\
\text { Rhosa } \\
\text { Beeson } \\
\text { [86,108-111] }\end{array}$ & Chromosome 2 & P3 $[53,86,104]$ & $\begin{array}{c}\text { Non-NLR genes } \\
\text { (RNase-H family protein) [65] }\end{array}$ \\
\hline Rsv5 & G1 [106] & $\begin{array}{c}\text { York } \\
\text { Dorman } \\
\text { Arksoy } \\
\text { Riple } \\
\text { Calhoun } \\
\text { Musen [106] }\end{array}$ & Chromosome 13 & Possibly P3 & unknown \\
\hline
\end{tabular}




\subsection{Rsc Genes}

The nation-wide SMV strain identification system in China includes 22 SMV strains, designated as SC1-SC22. These strains are identified based on their response to 10 dominant soybean cultivars that are distributed in different areas in China $[29,35,36]$. Genes conferring resistance to SC strains are designated as Rsc resistance genes and mapped to the same chromosomes as Rsv genes (chromosome 13, 14, and 2) (Table 3) [6,35].

Table 3. Summary of the genes that confer resistance to SMV-SC strains.

\begin{tabular}{|c|c|c|c|c|}
\hline R gene & SMV Strain & Cultivar & Location & Candidate Genes \\
\hline Rsc7 & SC7 & Kefeng No.1 [112,113] & $\begin{array}{c}\text { Chromosome 2 } \\
\text { Linked markers (distance): } \\
\text { Satt266 }(43.7 \mathrm{cM}) \\
\text { Satt634 }(18.1 \mathrm{cM}) \\
\text { Satt558 }(26.6 \mathrm{cM}) \\
\text { Satt157 }(36.4 \mathrm{cM}) \\
\text { Satt698 }(37.9 \mathrm{cM}) \\
{[112]} \\
\text { Flanking markers: } \\
\text { BARCSOYSSR_02_0621 } \\
\text { BARCSOYSSR_02_0632 [113] }\end{array}$ & $\begin{array}{l}15 \text { candidate genes with one NBS-LRR } \\
\text { type gene, one HSP } 40 \text { gene and one } \\
\text { serine carboxypeptidase-type gene [113] }\end{array}$ \\
\hline $\operatorname{Rsc} 8$ & SC8 & Kefeng No.1 [32] & $\begin{array}{c}\text { Chromosome 2 } \\
\text { Flanking markers: } \\
\text { BARCSOYSSR_02_0610 } \\
\text { BARCSOYSSR_02_0616 [32] } \\
\text { Other markers: } \\
\text { ZL-42 and ZL-52 }\end{array}$ & $\begin{array}{l}\text { Glyma02g13310, Glyma02g13320, } \\
\text { Glyma02g13400, Glyma02g13460, } \\
\text { Glyma02g13470 [32] } \\
\text { Glyma02g121500 and Glyma02g121600 } \\
\text { (encoding MADS-box proteins) [114] }\end{array}$ \\
\hline Rsc5 & SC5 & Kefeng No1 [28] & $\begin{array}{c}\text { Chromosome 2 } \\
\text { Flanking markers: } \\
\text { Bin } 352 \\
\text { Bin353 [28] } \\
\end{array}$ & $\begin{array}{l}11 \text { candidate genes with Glyma02g13495 } \\
\text { as the most plausible candidate [28] }\end{array}$ \\
\hline$R s c 20$ & SC20 & Qihuang-1 [29] & $\begin{array}{c}\text { Chromosome 13 } \\
\text { Flanking markers: } \\
\text { BARCSOYSSR_13_1099 } \\
\text { BARCSOYSSR_13_1185 [29] }\end{array}$ & $\begin{array}{l}\text { TIR-NBS-LRR type R genes: } \\
\text { Glyma13g194700 and Glyma13g195100 } \\
\text { [29]. }\end{array}$ \\
\hline Rsc12 & SC12 & Qihuang-22 [115] & $\begin{array}{c}\text { Chromosome } 13 \\
\text { Flanking marker: } \\
\text { Satt334 } \\
\text { Sct_033 [115] } \\
\end{array}$ & \\
\hline$R s c 3$ & SC3 & Qihuang-1 [116] & Chromosome 13 [116] & $\begin{array}{l}\text { Glyma13g25920, Glyma13g25950, } \\
\text { Glyma13g25970, and Glyma13g26000 [116] }\end{array}$ \\
\hline$R s c 3 Q$ & SC3 & Qihuang-1 [117] & $\begin{array}{c}\text { Chromosome 13 } \\
\text { Flanking markers: } \\
\text { BARCSOYSSR_13_1114 } \\
\text { BARCSOYSSR_13_1136 [117] }\end{array}$ & $\begin{array}{l}\text { Glyma13g25730, Glyma13g25750, } \\
\text { Glyma13g25950, Glyma13g25970, and } \\
\text { Glyma13g26000 [117]. }\end{array}$ \\
\hline$R s c 14 Q$ & SC14 & Qihuang-1 [118,119] & $\begin{array}{l}\text { Chromosome 13 } \\
\text { Flanking markers: } \\
\text { Sat_234 } \\
\text { Sct_033 [118] } \\
\text { Other markers: } \\
\text { Satt334 } \\
\text { MY750 [119] } \\
\end{array}$ & \\
\hline Rsc18 & SC18 & $\begin{array}{l}\text { Kefeng No.1 [120] } \\
\text { Qihuang-22 [120] }\end{array}$ & $\begin{array}{c}\text { Chromosome 2 } \\
\text { Flanking marker: } \\
\text { BARCSOYSSR_02_0667 } \\
\text { BARCSOYSSR_02_0670[120] } \\
\text { Chromosome 13 } \\
\text { Flanking marker: } \\
\text { SOYHSP176 } \\
\text { Satt334 [120] }\end{array}$ & $\begin{array}{l}\text { Glyma02g127800, Glyma02g128200 and } \\
\text { Glyma02g128300 [120] }\end{array}$ \\
\hline Rsc4 & SC4 & Dabaima [121] & $\begin{array}{c}\text { Chromosome 14 } \\
\text { Flanking markers: } \\
\text { BARCSOYSSR_14_1413 } \\
\text { BARCSOYSSR_14_1416[31] }\end{array}$ & $\begin{array}{l}\text { NB-LRR genes: Glyma14g38510 and } \\
\text { Glyma14g38560 } \\
\text { P450 family gene: } \\
\text { Glyma14g38580 [31] }\end{array}$ \\
\hline
\end{tabular}


Apart from those genes indicated in Table 3, a novel locus discovered on chromosome 6 was found responsible for SMV-resistance in the soybean cultivar RN-9 [30]. The new locus was designated as Rsc15 and was mapped to a 14.6-cM region which is flanked by two SSR markers: SSR_06_17 and BARCSOYSSR_06_0835 [30]. In RN-9, the expression of Rsc15 during early stages of SMV-SC15 infection was highly correlated with hydrogen peroxide $\left(\mathrm{H}_{2} \mathrm{O}_{2}\right)$ levels and peroxidase (POD) activity [30]. Glyma06g182600 was designated as GmPEX14 and proposed as the strongest candidate gene of Rsc15. It encodes a peroxisomal membrane anchor protein and has a polymorphism in the DNA/cDNA sequence alignments. Infection by SC15 increased the expression of GmPEX14 and induced the $\mathrm{H}_{2} \mathrm{O}_{2}$ burst in the resistant cultivar RN-9 [30]. This suggests that peroxidases are probably involved in Rsc15-mediated resistance to SC15.

In addition to single dominant resistance genes, a combination of SMV resistance genes has also been reported in China. Crosses between soybean cultivars Qihuang1 $x$ Kefeng 1 and Dabaima $x$ Nannong 1138-2 resulted in plants carrying $R s c 4, R s c 8$, and $R s c 14 Q$ genes, which confer resistance to 21 strains of SMV in China [33]. In addition, pyramiding has been used to obtain soybean lines with combinations of resistance genes. Gene pyramiding in Essex cultivar was used to generate Rsv1Rsv3, Rsv1Rsv4, and Rsv1Rsv3Rsv4 isolines which are resistant to strains G1 to G7. However, the isolines Rsv3Rsv4 was susceptible to G1 [26].

Given the diversity of Rsc genes and Rsc loci, and the different types of those genes, functional characterizations are required to understand the molecular bases of Rsc-mediated resistance against various SMV SC strains.

\section{Independent Host Factors Involved in Soybean-SMV Interaction}

Several independent host factors with defense roles are involved in soybean-SMV interaction (Table 4). The GmeEF1A protein is hijacked by the SMV P3 protein to promote SMV replication, evidenced by inhibition of SMV accumulation in GmEF1A-silenced plants [51]. Mitogen-activated protein kinase (MPKs) cascades are universal signal transductions that are involved in responses to various biotic and abiotic stresses, hormone signaling, cell division and developmental processes [122]. GmMPK4, a homolog of mitogen-activated protein kinase-4 in soybean, negatively regulates SA accumulation and defense responses [123]. Silencing of GmMPK4 resulted in stunted phenotype and cell death on the leaves and stems in the silenced plants. In addition, increase of SA and $\mathrm{H}_{2} \mathrm{O}_{2}$ accumulation was observed in the GmMPK4-silenced plants [123]. Silencing of GmMPK6 in soybean plants caused stunted phenotypes and spontaneous cell death on the systemic leaves. Furthermore, a significant increase of pathogenesis-related $(P R)$ genes and the conjugated form of SA were also observed in the silenced plants, suggesting that defense response is activated in GmMPK6-silenced plants even without virus infection [124]. Plants silenced with GmMPK6 exhibited increased resistance to SMV and downy mildew infections compared with control plants. This indicates that GmMPK6, similar to GmMPK4, is a negative regulator of soybean defense responses [124]. Interestingly, transient overexpression of GmMPK6 in N.benthamiana or GmMPK6-transgenic Arabidopsis showed HR-like cell death symptoms without virus infection [124]. Pathogenesis-related genes were highly induced in the transgenic Arabidopsis plants, suggesting a positive role of GmMPK6 in defense response in Arabidopsis [124]. These results suggest a complexity function of GmMPK6 as both repressor and activator of defense responses depending on the host. 
Table 4. Summary of host factors or genes involved in resistance to SMV.

\begin{tabular}{ccc}
\hline Host Factors & Roles in SMV Resistance & Reference \\
\hline eEF1A & Targeted by P3, promotes SMV replication & {$[51]$} \\
\hline GmEDR1, GmEDS1 GmPAD4 & Induce accumulation of SA, mediated resistance against SMV & {$[17]$} \\
\hline GmHSP90 & Reduced the replication and movement of SMV-G2 (Rsv1-mediated resistance) & {$[17]$} \\
\hline WRKY6 & Rsv1-mediated resistance against SMV-G2 & {$[17]$} \\
WRKY30 & Induces callose accumulation, restricts SMV movement & {$[100]$} \\
\hline GmPP2C3a & Induces burst of $\mathrm{H}_{2} \mathrm{O}_{2,}($ Rsc15-mediated resistance) & {$[30]$} \\
\hline GmPEX14 & Negatively regulates SA accumulation and defense response & {$[123]$} \\
\hline GmMPK4 & Repressor and activator in defense response & {$[124]$} \\
\hline GmMPK6 & Stimulates ABA accumulation & {$[25]$} \\
\hline GmKR3 & Targets the P3 protein to inhibit SMV accumulation & {$[24]$} \\
\hline GmCYB5 &
\end{tabular}

Cytochrome B5 ( $G m C Y B 5)$, a gene from a class of heme proteins associated with the endoplasmic reticulum in soybean, reduce MV-SC15 accumulation [24]. In response to infection with SMV-SC15, the expression of $\mathrm{GmCYB5}$ is upregulated to a much greater degree in RN-9 resistant cultivar than in NN1138-2 susceptible cultivar. Silencing GmCYB5 promotes SMV-SC15 accumulation in soybean RN-9. GmCYB5 physically interacts with the P3 protein of SMV-SC15 at the cell periphery and is suggested to interfere with the role of $\mathrm{P} 3$ in SMV replication [24].

Apart from individual genes involved in SMV-soybean interaction, the antiviral RNA silencing pathway has been also reported to be involved in soybean resistance to SMV [18,19,125]. The viral replication intermediate, i.e., double-stranded (ds) RNA, is sensed by RNase type III-like enzymes called Dicer-like (DCL) proteins, which cleave the dsRNA into primary short interfering (si) RNAs of 21-24 nucleotides (nt) in length [126]. Viral-derived siRNAs (vsiRNAs) are loaded into the RNA-induced silencing complex (RISC), where they guide argonaute proteins (AGO) to cleave the viral RNA genes upon perfect complementation between vsiRNA and viral genes [126,127]. In the Rsv3-cultivar L29, several genes in the antiviral RNA silencing pathway were induced in response to infection by the avirulent strain G5H but showed no change or even downregulation in response to infection by the virulent strain G7H [18]. This indicates that the antiviral RNA silencing pathway contributes to the ER against G5H. In addition, ABA treatment of soybean or Arabidopsis plants induces several genes in the antiviral RNA silencing pathway, which indicates that ABA acts upstream of the RNA silencing pathway and downstream of the Rsv3 sensor protein $[19,128]$. Interestingly, the effect of ABA on the expression of the RNA silencing genes was stronger in Rsv3-plants then in rsv-null plants [128].

Micro RNAs (miRNAs) target several host genes, including the NB-LRR resistance genes, in order to regulate plant responses to different stimuli [129]. The tobacco resistance gene $N$ is regulated by miR6019 and miR6020, while the potato PYV resistance gene Ry is regulated by miR482b [130]. Profiling of miRNAs in the soybean cultivar Williams 82 ( $r s v)$, which is susceptible to SMV, and in soybean cultivar P196983 (Rsv1), which is resistant to SMV-G2 but susceptible to SMV-G7, revealed that miR168 was upregulated only in the G7-infected PI96983 line and that the upregulation was associated with an LSHR [23]. miR168 regulates expression of AGO1, a key RNA-slicer enzyme in the antiviral RNA silencing pathway [131]. In another example, tomato infected with turnip crinkle virus (TCV), cucumber mosaic virus (CMV), or tobacco rattle virus (TRV) exhibited decreased levels of miR482, which allowed the transcript levels of targeted NLRs to increase [129].

Levels of other hormones such as cytokinins and brassinosteroids and expression levels of their related genes were mildly elevated in response to infection by SMV-G5H or SMV-G7H. Cytokinins and brassinosteroids have various functions in plant growth and development and also increase plant tolerance to infection by some viruses $[16,18,132]$. 
Several soybean transgenic lines have been developed for SMV resistance (Table 5). These transgenic lines were generated either by overexpressing resistance genes or by introducing SMV genetic elements to induce pathogen-derived resistance (PDR) [133]. A recent study documented a transgenic soybean that targets the soybean endogenous gene, eIF4E, via an RNA interference approach [134]. The eIF4E protein is required for the accumulation of the several potyviruses, and thus is considered as a major susceptibility factor for several RNA viruses [135]. Yeast two-hybrid and bimolecular fluorescence complementation assays showed that eIF4E1 interacted with Vpg protein in the nucleus and with Nia-Pro/NIb in the cytoplasm, which suggests that eIF4E is involved in SMV replication [135]. Generation of transgenic soybean plants silenced for eIF4E1 showed robust and broad-spectrum resistance in T1 and T2 generation against SMV-SC3, SC7, SC15, SC18, and SMV-R [135].

Table 5. Summary of SMV-tolerant cultivars.

\begin{tabular}{|c|c|c|}
\hline Tolerance Cultivar & & Reference \\
\hline RNAi-mediated silencing of SMV P3 transgenic soybean & $\begin{array}{c}\text { Exhibited stable and enhanced resistance to SMV SC3 and } \\
\text { other potyviruses. }\end{array}$ & [137] \\
\hline Transgenic GmKR3 & $\begin{array}{l}\text { Enhances resistance against multiple viruses, including } \\
\text { SMV-SC3, via ABA signaling }\end{array}$ & [25] \\
\hline SMV-CP-RNAi transgenic soybean & $\begin{array}{l}\text { Induces a functional gene silencing system and resulted in a } \\
\text { viral-resistant phenotype. }\end{array}$ & [139] \\
\hline Inverted repeat-SMV-HC-pro transgenic soybean & $\begin{array}{l}\text { Induced RNA-mediated resistance via RNAi by targeting } \\
\text { SMV-HC-pro }\end{array}$ & [140] \\
\hline Soybean RNA interfere lines, silenced for eIF4E & $\begin{array}{l}\text { Interferes viral replication cycles, increases broad-spectrum } \\
\text { resistance against SMV-SC3, SC7,SC-15,SC18, and SMV-R }\end{array}$ & [134] \\
\hline
\end{tabular}

\section{Conclusions and Future Perspectives}

Several studies have been carried out to characterize SMV-soybean interactions leading to the identification of several $R$-genes such as the $R s v$ and $R s c$ genes as well as a few other individual genes required for resistance $[15,24,35,88,102,141]$. However, the molecular mechanisms underlying many of which are still lacking, and further investigations would help understand how resistant cultivars achieve resistance against various SMV strains so they can be transferred to susceptible cultivars or species [24,136]. Nonetheless, many new SMV strains have also emerged with counter-defense weapons evolved over natural selection in the field [8,9]. Their abilities to break high-specific resistance also require further investigation to determine the elements involved in resistance breaking, which in many cases involved recognition avoidance by R-proteins [8,9]. A good breeding-for-resistance strategy would aim to develop cultivars with resistance against a wide range of strains, where new molecular tools, such as CRISPR/Cas9 (which knocks out specific genes by deletion) or RNAi (which silences specific genes) can speed up the breeding program. The use of CRISPR/Cas9 in generating lines disrupted with eIF4E, a host factor required for virus replication, proved successful in generating cucumber plants with resistance to zucchini yellow mosaic virus and papaya ring spot mosaic virus-W [142]. In addition, the use of RNAi techniques to generate transgenic lines expressing fragments from SMV genes has been shown to be efficient in inducing resistance against SMV (Table 5). For instance, transgenic soybean lines expressing part of the P3 and HC-pro genes showed a stable and enhanced resistance to SMV-SC3, -SC7, -SC15, -SC18, and -R (a novel recombinant strain found in China) and have the potential to significantly increase soybean yield [137,143]. With the continuous discoveries of defense mechanisms and the implementation of new molecular tools in breeding programs, generating efficient resistant plants will be faster to achieve.

Author Contributions: M.A. provided the key ideas of the review; M.A. and K.W. jointly wrote the manuscript; K.W. prepared the figures and table; M.A. and K.-H.K. revised and edited the manuscript and acquired the funding. All authors have read and agreed to the published version of the manuscript. 
Funding: This research was supported in part by grants from the Next-Generation BioGreen 21 Program (No. PJ013225), the Rural Development Administration (RDA), and the Korea Research Fellowship program funded by the Ministry of Science and ICT through the National Research Foundation of Korea (KRF Grant No. 2017H1D3A1A01054585), Republic of Korea. KW was supported by a research fellowship from the Brain Korea 21 Plus Project.

Conflicts of Interest: The authors declare no conflict of interest.

\section{References}

1. Hartman, G.L.; West, E.D.; Herman, T.K. Crops that feed the World 2. Soybean-Worldwide production, use, and constraints caused by pathogens and pests. J. Food Secur. 2011, 3, 5-17. [CrossRef]

2. Pagano, M.C.; Miransari, M. The importance of Soybean Production Worldwide; Elsevier: Amsterdam, The Netherlands, 2016; pp. 1-26.

3. Hill, J.H.; Whitham, S.A. Control of virus diseases in soybeans. Adv. Virus Res. 2014, 90, 355-390. [PubMed]

4. Malapi-Nelson, M.; Wen, R.-H.; Ownley, B.; Hajimorad, M. Co-infection of soybean with Soybean mosaic virus and Alfalfa mosaic virus results in disease synergism and alteration in accumulation level of both viruses. Plant Dis. 2009, 93, 1259-1264. [CrossRef] [PubMed]

5. Hartman, G.L.; Hill, C.B. 13 Diseases of Soybean and Their Management; CABI: USA, 2010; p. 276.

6. Hajimorad, M.; Domier, L.L.; Tolin, S.; Whitham, S.; Saghai Maroof, M. Soybean mosaic virus: A successful potyvirus with a wide distribution but restricted natural host range. Mol. Plant Pathol. 2018, 19, 1563-1579. [CrossRef] [PubMed]

7. Galvez, L.C.; Banerjee, J.; Pinar, H.; Mitra, A. Engineered plant virus resistance. Plant Sci. 2014, 228, 11-25. [CrossRef]

8. Choi, B.K.; Koo, J.M.; Ahn, H.J.; Yum, H.J.; Choi, C.W.; Ryu, K.H.; Chen, P.; Tolin, S. Emergence of Rsv resistance breaking Soybean mosaic virus isolates from Korean soybean cultivars. Virus Res. 2005, 112, $42-51$. [CrossRef]

9. Koo, J.; Choi, B.; Ahn, H.; Yum, H.; Choi, C. First report of an Rsv resistance-breaking isolate of Soybean mosaic virus in Korea. Plant Pathol. 2005, 54, 573. [CrossRef]

10. Kang, B.-C.; Yeam, I.; Jahn, M.M. Genetics of plant virus resistance. Annu. Rev. Phytopathol. 2005, 43, 581-621. [CrossRef]

11. Calvo, M.; Martínez-Turiño, S.; García, J.A. Resistance to Plum pox virus Strain C in Arabidopsis thaliana and Chenopodium foetidum involves genome-linked viral protein and other viral determinants and might depend on compatibility with host translation initiation factors. Mol. Plant-Microbe Interact. 2014, 27, 1291-1301. [CrossRef]

12. Hashimoto, M.; Neriya, Y.; Yamaji, Y.; Namba, S. Recessive resistance to plant viruses: Potential resistance genes beyond translation initiation factors. Front. Microbiol. 2016, 7, 1695. [CrossRef]

13. Baebler, S.; Witek, K.; Petek, M.; Stare, K.; Tusek-Znidaric, M.; Pompe-Novak, M.; Renaut, J.; Szajko, K.; Strzelczyk-Zyta, D.; Marczewski, W.; et al. Salicylic acid is an indispensable component of the Ny-1 resistance-gene-mediated response against Potato virus $\mathrm{Y}$ infection in potato. J. Exp. Bot. 2014, 65, 1095-1109. [CrossRef]

14. Hajimorad, M.R.; Eggenberger, A.L.; Hill, J.H. Loss and gain of elicitor function of soybean mosaic virus G7 provoking Rsv1-mediated lethal systemic hypersensitive response maps to P3. J. Virol. 2005, 79, 1215-1222. [CrossRef] [PubMed]

15. Hajimorad, M.; Hill, J. Rsv1-mediated resistance against Soybean mosaic virus-N is hypersensitive response-independent at inoculation site, but has the potential to initiate a hypersensitive response-like mechanism. Mol. Plant Microbe Interact. 2001, 14, 587-598. [CrossRef] [PubMed]

16. Alazem, M.; Lin, N.S. Roles of plant hormones in the regulation of host-virus interactions. Mol. Plant Pathol. 2015, 16, 529-540. [CrossRef] [PubMed]

17. Zhang, C.; Grosic, S.; Whitham, S.A.; Hill, J.H. The requirement of multiple defense genes in soybean Rsv1-mediated extreme resistance to Soybean mosaic virus. Mol. Plant Microbe Interact. 2012, 25, 1307-1313. [CrossRef] [PubMed]

18. Alazem, M.; Tseng, K.-C.; Chang, W.-C.; Seo, J.-K.; Kim, K.-H. Elements Involved in the Rsv3-Mediated Extreme Resistance against an Avirulent Strain of Soybean Mosaic Virus. Viruses 2018, 10, 581. [CrossRef] 
19. Alazem, M.; Widyasari, K.; Kim, K.H. An Avirulent Strain of Soybean Mosaic Virus Reverses the Defensive Effect of Abscisic Acid in a Susceptible Soybean Cultivar. Viruses 2019, 11, 879. [CrossRef]

20. Alazem, M.; He, M.H.; Moffett, P.; Lin, N.S. Abscisic Acid Induces Resistance against Bamboo Mosaic Virus through Argonaute2 and 3. Plant Physiol. 2017, 174, 339-355. [CrossRef]

21. Alazem, M.; Lin, N.S. Antiviral Roles of Abscisic Acid in Plants. Front. Plant Sci. 2017, 8, 1760. [CrossRef]

22. Xie, K.; Li, L.; Zhang, H.; Wang, R.; Tan, X.; He, Y.; Hong, G.; Li, J.; Ming, F.; Yao, X.; et al. Abscisic acid negatively modulates plant defence against rice black-streaked dwarf virus infection by suppressing the jasmonate pathway and regulating reactive oxygen species levels in rice. Plant Cell Environ. 2018, 41, 2504-2514. [CrossRef]

23. Chen, H.; Zhang, L.; Yu, K.; Wang, A. Pathogenesis of Soybean mosaic virus in soybean carrying Rsv1 gene is associated with miRNA and siRNA pathways, and breakdown of AGO1 homeostasis. Virology 2015, 476, 395-404. [CrossRef] [PubMed]

24. Luan, H.; Niu, H.; Luo, J.; Zhi, H. Soybean Cytochrome b5 Is a Restriction Factor for Soybean Mosaic Virus. Viruses 2019, 11, 546. [CrossRef] [PubMed]

25. Xun, H.; Yang, X.; He, H.; Wang, M.; Guo, P.; Wang, Y.; Pang, J.; Dong, Y.; Feng, X.; Wang, S.; et al. Over-expression of GmKR3, a TIR-NBS-LRR type R gene, confers resistance to multiple viruses in soybean. Plant Mol. Biol. 2019, 99, 95-111. [CrossRef] [PubMed]

26. Maroof, S.; Jeong, S.C.; Gunduz, I.; Tucker, D.; Buss, G.; Tolin, S. Pyramiding of soybean mosaic virus resistance genes by marker-assisted selection. Crop Sci. 2008, 48, 517-526. [CrossRef]

27. Shakiba, E.; Chen, P.; Shi, A.; Li, D.; Dong, D.; Brye, K. Two novel alleles at the Rsv 3 locus for resistance to Soybean mosaic virus in PI 399091 and PI 61947 soybeans. Crop Sci. 2012, 52, 2587-2594. [CrossRef]

28. Karthikeyan, A.; Li, K.; Jiang, H.; Ren, R.; Li, C.; Zhi, H.; Chen, S.; Gai, J. Inheritance, fine-mapping, and candidate gene analyses of resistance to soybean mosaic virus strain SC5 in soybean. Mol. Genet. Genomics 2017, 292, 811-822. [CrossRef]

29. Karthikeyan, A.; Li, K.; Li, C.; Yin, J.; Li, N.; Yang, Y.; Song, Y.; Ren, R.; Zhi, H.; Gai, J.; et al. Fine-mapping and identifying candidate genes conferring resistance to Soybean mosaic virus strain SC20 in soybean. Theor. Appl. Genet. 2018, 131, 461-476. [CrossRef]

30. Rui, R.; Liu, S.; Karthikeyan, A.; Wang, T.; Niu, H.; Yin, J.; Yang, Y.; Wang, L.; Yang, Q.; Zhi, H.; et al. Fine-mapping and identification of a novel locus Rsc15 underlying soybean resistance to Soybean mosaic virus. Theor. Appl. Genet. 2017, 130, 2395-2410. [CrossRef]

31. Wang, D.; Ma, Y.; Liu, N.; Yang, Z.; Zheng, G.; Zhi, H. Fine mapping and identification of the soybean RSC4 resistance candidate gene to soybean mosaic virus. Plant Breed. 2011, 130, 653-659. [CrossRef]

32. Wang, D.; Ma, Y.; Yang, Y.; Liu, N.; Li, C.; Song, Y.; Zhi, H. Fine mapping and analyses of R SC8 resistance candidate genes to soybean mosaic virus in soybean. Theor. Appl. Genet. 2011, 122, 555-565. [CrossRef]

33. Wang, D.-G.; Lin, Z.; Kai, L.; Ying, M.; Wang, L.-Q.; Yang, Y.-Q.; Yang, Y.-H.; Zhi, H.-J. Marker-assisted pyramiding of soybean resistance genes RSC4, RSC8, and RSC14Q to soybean mosaic virus. J. Integr. Agric. 2017, 16, 2413-2420. [CrossRef]

34. Cho, E.-K.; Goodman, R.M. Strains of soybean mosaic virus: Classification based on virulence in resistant soybean cultivars. Phytopathology 1979, 69, 467-470. [CrossRef]

35. Li, K.; Yang, Q.; Zhi, H.; Gai, J. Identification and distribution of soybean mosaic virus strains in southern China. Plant Dis. 2010, 94, 351-357. [CrossRef]

36. Wang, D.; Tian, Z.; Li, K.; Li, H.; Huang, Z.; Hu, G.; Zhang, L.; Zhi, H. Identification and variation analysis of soybean mosaic virus strains in Shandong, Henan and Anhui provinces of China. Soybean Science 2013, 32, 806-809.

37. Riechmann, J.L.; Lain, S.; García, J.A. Highlights and prospects of potyvirus molecular biology. J. Gen. Virol. 1992, 73, 1-16. [CrossRef] [PubMed]

38. Olspert, A.; Chung, B.Y.W.; Atkins, J.F.; Carr, J.P.; Firth, A.E. Transcriptional slippage in the positive-sense RNA virus family Potyviridae. EMBO Rep. 2015, 16, 995-1004. [CrossRef] [PubMed]

39. Revers, F.; García, J.A. Molecular biology of potyviruses. Adv. Virus Res. 2015, 92, 101-199.

40. Chung, B.Y.-W.; Miller, W.A.; Atkins, J.F.; Firth, A.E. An overlapping essential gene in the Potyviridae. Proc. Natl. Acad. Sci. USA 2008, 105, 5897-5902. [CrossRef]

41. Verchot, J.; Carrington, J.C. Evidence that the potyvirus P1 proteinase functions in trans as an accessory factor for genome amplification. J. Virol. 1995, 69, 3668-3674. [CrossRef] 
42. Kapust, R.B.; Tözsér, J.; Copeland, T.D.; Waugh, D.S. The P1' specificity of tobacco etch virus protease. Biochem. Biophys. Res. Commun. 2002, 294, 949-955. [CrossRef]

43. Maliogka, V.I.; Salvador, B.; Carbonell, A.; Saenz, P.; León, D.S.; Oliveros, J.C.; Delgadillo, M.O.; García, J.A.; Simón-Mateo, C. Virus variants with differences in the P1 protein coexist in a Plum pox virus population and display particular host-dependent pathogenicity features. Mol. Plant Pathol. 2012, 13, 877-886. [CrossRef] [PubMed]

44. Salvador, B.; Saenz, P.; Yangüez, E.; Quiot, J.B.; Quiot, L.; Delgadillo, M.O.; Garcia, J.A.; Simón-Mateo, C. Host-specific effect of P1 exchange between two potyviruses. Mol. Plant Pathol. 2008, 9, 147-155. [CrossRef] [PubMed]

45. Kasschau, K.D.; Carrington, J.C. Long-distance movement and replication maintenance functions correlate with silencing suppression activity of potyviral HC-Pro. Virology 2001, 285, 71-81. [CrossRef] [PubMed]

46. Peng, Y.; Kadoury, D.; Gal-On, A.; Huet, H.; Wang, Y.; Raccah, B. Mutations in the HC-Pro gene of zucchini yellow mosaic potyvirus: Effects on aphid transmission and binding to purified virions. J. Gen. Virol. 1998, 79, 897-904. [CrossRef]

47. Seo, J.K.; Kang, S.H.; Seo, B.Y.; Jung, J.K.; Kim, K.H. Mutational analysis of interaction between coat protein and helper component-proteinase of Soybean mosaic virus involved in aphid transmission. Mol. Plant Pathol. 2010, 11, 265-276. [CrossRef]

48. Kasschau, K.D.; Carrington, J.C. A counterdefensive strategy of plant viruses: Suppression of posttranscriptional gene silencing. Cell 1998, 95, 461-470. [CrossRef]

49. Wen, R.-H.; Khatabi, B.; Ashfield, T.; Maroof, M.S.; Hajimorad, M. The HC-Pro and P3 cistrons of an avirulent Soybean mosaic virus are recognized by different resistance genes at the complex Rsv1 locus. Mol. Plant Microbe Interact. 2013, 26, 203-215. [CrossRef]

50. Eggenberger, A.; Hajimorad, M.; Hill, J. Gain of virulence on Rsv1-genotype soybean by an avirulent Soybean mosaic virus requires concurrent mutations in both P3 and HC-Pro. Mol. Plant Microbe Interact. 2008, 21, 931-936. [CrossRef]

51. Luan, H.; Shine, M.; Cui, X.; Chen, X.; Ma, N.; Kachroo, P.; Zhi, H.; Kachroo, A. The potyviral P3 protein targets eukaryotic elongation factor $1 \mathrm{~A}$ to promote the unfolded protein response and viral pathogenesis. Plant Physiol. 2016, 172, 221-234. [CrossRef]

52. Hajimorad, M.; Eggenberger, A.; Hill, J. Strain-specific P3 of Soybean mosaic virus elicits Rsv1-mediated extreme resistance, but absence of $\mathrm{P} 3$ elicitor function alone is insufficient for virulence on Rsv1-genotype soybean. Virology 2006, 345, 156-166. [CrossRef]

53. Chowda-Reddy, R.; Sun, H.; Chen, H.; Poysa, V.; Ling, H.; Gijzen, M.; Wang, A. Mutations in the P3 protein of Soybean mosaic virus G2 isolates determine virulence on Rsv4-genotype soybean. Mol. Plant Microbe Interact. 2011, 24, 37-43. [CrossRef] [PubMed]

54. Wen, R.-H.; Hajimorad, M. Mutational analysis of the putative pipo of soybean mosaic virus suggests disruption of PIPO protein impedes movement. Virology 2010, 400, 1-7. [CrossRef] [PubMed]

55. Hong, X.-Y.; Chen, J.; Shi, Y.-H.; Chen, J.-P. The '6K1'protein of a strain of Soybean mosaic virus localizes to the cell periphery. Arch. Virol. 2007, 152, 1547-1551. [CrossRef] [PubMed]

56. Carrington, J.C.; Jensen, P.E.; Schaad, M.C. Genetic evidence for an essential role for potyvirus CI protein in cell-to-cell movement. Plant J. 1998, 14, 393-400. [CrossRef]

57. Seo, J.-K.; Lee, S.-H.; Kim, K.-H. Strain-specific cylindrical inclusion protein of Soybean mosaic virus elicits extreme resistance and a lethal systemic hypersensitive response in two resistant soybean cultivars. Mol. Plant Microbe Interact. 2009, 22, 1151-1159. [CrossRef]

58. Zhang, C.; Hajimorad, M.; Eggenberger, A.L.; Tsang, S.; Whitham, S.A.; Hill, J.H. Cytoplasmic inclusion cistron of Soybean mosaic virus serves as a virulence determinant on Rsv3-genotype soybean and a symptom determinant. Virology 2009, 391, 240-248. [CrossRef]

59. Wei, T.; Wang, A. Biogenesis of cytoplasmic membranous vesicles for plant potyvirus replication occurs at endoplasmic reticulum exit sites in a COPI-and COPII-dependent manner. J. Virol. 2008, 82, 12252-12264. [CrossRef]

60. Wei, T.; Huang, T.-S.; McNeil, J.; Laliberté, J.-F.; Hong, J.; Nelson, R.S.; Wang, A. Sequential recruitment of the endoplasmic reticulum and chloroplasts for plant potyvirus replication. J. Virol. 2010, 84, 799-809. [CrossRef] 
61. Michon, T.; Estevez, Y.; Walter, J.; German-Retana, S.; Le Gall, O. The potyviral virus genome-linked protein VPg forms a ternary complex with the eukaryotic initiation factors eIF4E and eIF4G and reduces eIF4E affinity for a mRNA cap analogue. FEBS J. 2006, 273, 1312-1322. [CrossRef]

62. Lellis, A.D.; Kasschau, K.D.; Whitham, S.A.; Carrington, J.C. Loss-of-susceptibility mutants of Arabidopsis thaliana reveal an essential role for eIF (iso) 4E during potyvirus infection. Curr. Biol. 2002, 12, 1046-1051. [CrossRef]

63. Carrington, J.C.; Freed, D.D.; Leinicke, A.J. Bipartite signal sequence mediates nuclear translocation of the plant potyviral NIa protein. Plant Cell 1991, 3, 953-962. [PubMed]

64. Adams, M.J.; Antoniw, J.F.; Beaudoin, F. Overview and analysis of the polyprotein cleavage sites in the family Potyviridae. Mol. Plant Pathol. 2005, 6, 471-487. [CrossRef] [PubMed]

65. Ishibashi, K.; Saruta, M.; Shimizu, T.; Shu, M.; Anai, T.; Komatsu, K.; Yamada, N.; Katayose, Y.; Ishikawa, M.; Ishimoto, M.; et al. Soybean antiviral immunity conferred by dsRNase targets the viral replication complex. Nat. Commun. 2019, 10, 4033. [CrossRef] [PubMed]

66. Charon, J.; Theil, S.; Nicaise, V.; Michon, T. Protein intrinsic disorder within the Potyvirus genus: From proteome-wide analysis to functional annotation. Mol. Biosyst. 2016, 12, 634-652. [CrossRef]

67. Hong, Y.; Hunt, A.G. RNA polymerase activity catalyzed by a potyvirus-encoded RNA-dependent RNA polymerase. Virology 1996, 226, 146-151. [CrossRef]

68. Kang, S.-H.; Lim, W.-S.; Hwang, S.-H.; Park, J.-W.; Choi, H.-S.; Kim, K.-H. Importance of the C-terminal domain of soybean mosaic virus coat protein for subunit interactions. J. Gen. Virol. 2006, 87, 225-229. [CrossRef]

69. Steinlage, T.A.; Hill, J.; Nutter Jr, F. Temporal and spatial spread of Soybean mosaic virus (SMV) in soybeans transformed with the coat protein gene of SMV. Phytopathology 2002, 92, 478-486. [CrossRef]

70. Helm, M.; Qi, M.; Sarkar, S.; Yu, H.; Whitham, S.A.; Innes, R.W. Engineering a decoy substrate in soybean to enable recognition of the Soybean Mosaic Virus NIa protease. Mol. Plant Microbe Interact. 2019, 32, 760-769. [CrossRef]

71. Reagan, B.C.; Burch-Smith, T.M. Viruses Reveal the Secrets of Plasmodesmal Cell Biology. Mol. Plant Microbe Interact. 2019, 33, 26-39. [CrossRef]

72. Otulak-Kozieł, K.; Kozieł, E.; Lockhart, B. Plant cell wall dynamics in compatible and incompatible potato response to infection caused by Potato virus Y (PVYNTN). Int. J. Mol. Sci. 2018, 19, 862. [CrossRef]

73. Allie, F.; Pierce, E.J.; Okoniewski, M.J.; Rey, C. Transcriptional analysis of South African cassava mosaic virus-infected susceptible and tolerant landraces of cassava highlights differences in resistance, basal defense and cell wall associated genes during infection. BMC Genomics 2014, 15, 1006. [CrossRef] [PubMed]

74. Wei, T.; Zhang, C.; Hong, J.; Xiong, R.; Kasschau, K.D.; Zhou, X.; Carrington, J.C.; Wang, A. Formation of complexes at plasmodesmata for potyvirus intercellular movement is mediated by the viral protein P3N-PIPO. PLoS Pathog. 2010, 6, e1000962. [CrossRef] [PubMed]

75. Vijayapalani, P.; Maeshima, M.; Nagasaki-Takekuchi, N.; Miller, W.A. Interaction of the trans-frame potyvirus protein P3N-PIPO with host protein PCaP1 facilitates potyvirus movement. PLoS Pathog. 2012, 8, e1002639. [CrossRef] [PubMed]

76. Nachappa, P.; Culkin, C.T.; Saya, P.M.; Han, J.; Nalam, V.J. Water stress modulates soybean aphid performance, feeding behavior, and virus transmission in soybean. Front. Plant Sci. 2016, 7, 552. [CrossRef] [PubMed]

77. Jossey, S.; Hobbs, H.A.; Domier, L.L. Role of Soybean mosaic virus-encoded proteins in seed and aphid transmission in soybean. Phytopathology 2013, 103, 941-948. [CrossRef]

78. Noman, A.; Aqeel, M.; Lou, Y. PRRs and NB-LRRs: From signal perception to activation of plant innate immunity. Int. J. Mol. Sci. 2019, 20, 1882. [CrossRef]

79. Wu, C.-H.; Abd-El-Haliem, A.; Bozkurt, T.O.; Belhaj, K.; Terauchi, R.; Vossen, J.H.; Kamoun, S. NLR network mediates immunity to diverse plant pathogens. Proc. Natl. Acad. Sci. USA 2017, 114, 8113-8118. [CrossRef]

80. Cesari, S. Multiple strategies for pathogen perception by plant immune receptors. New Phytol. 2018, 219, 17-24. [CrossRef]

81. Adachi, H.; Derevnina, L.; Kamoun, S. NLR singletons, pairs, and networks: Evolution, assembly, and regulation of the intracellular immunoreceptor circuitry of plants. Curr. Opin. Plant Biol. 2019, 50, 121-131. [CrossRef]

82. McHale, L.; Tan, X.; Koehl, P.; Michelmore, R.W. Plant NBS-LRR proteins: Adaptable guards. Genome Biol. 2006, 7, 212. [CrossRef] 
83. Deslandes, L.; Olivier, J.; Theulières, F.; Hirsch, J.; Feng, D.X.; Bittner-Eddy, P.; Beynon, J.; Marco, Y. Resistance to Ralstonia solanacearum in Arabidopsis thaliana is conferred by the recessive RRS1-R gene, a member of a novel family of resistance genes. Proc. Natl. Acad. Sci. USA 2002, 99, 2404-2409. [CrossRef] [PubMed]

84. Meyers, B.C.; Morgante, M.; Michelmore, R.W. TIR-X and TIR-NBS proteins: Two new families related to disease resistance TIR-NBS-LRR proteins encoded in Arabidopsis and other plant genomes. Plant J. 2002, 32, 77-92. [CrossRef] [PubMed]

85. Liu, J.-Z.; Fang, Y.; Pang, H. The current status of the soybean-soybean mosaic virus (SMV) pathosystem. Front. Microbiol. 2016, 7, 1906. [CrossRef] [PubMed]

86. Khatabi, B.; Fajolu, O.; Wen, R.H.; Hajimorad, M. Evaluation of N orth A merican isolates of S oybean mosaic virus for gain of virulence on Rsv-genotype soybeans with special emphasis on resistance-breaking determinants on Rsv4. Mol. Plant Pathol. 2012, 13, 1077-1088. [CrossRef]

87. Wang, Y.; Lu, J.; Chen, S.; Shu, L.; Palmer, R.G.; Xing, G.; Li, Y.; Yang, S.; Yu, D.; Zhao, T. Exploration of presence/absence variation and corresponding polymorphic markers in soybean genome. J. Integr. Plant Biol. 2014, 56, 1009-1019. [CrossRef]

88. Zhan, Y.; Zhi, H.; Yu, D.; Gai, J. Identification and distribution of SMV strains in huang-huai valleys. Agric. Sci. China 2006, 39, 2009-2015.

89. Hayes, A.; Jeong, S.; Gore, M.; Yu, Y.; Buss, G.; Tolin, S.; Maroof, M.S. Recombination within a nucleotide-binding-site/leucine-rich-repeat gene cluster produces new variants conditioning resistance to soybean mosaic virus in soybeans. Genetics 2004, 166, 493-503. [CrossRef]

90. Shi, A.; Chen, P.; Li, D.; Zheng, C.; Zhang, B.; Hou, A. Pyramiding multiple genes for resistance to soybean mosaic virus in soybean using molecular markers. Mol. Breed. 2009, 23, 113. [CrossRef]

91. Wang, J.; Shine, M.; Gao, Q.-M.; Navarre, D.; Jiang, W.; Liu, C.; Chen, Q.; Hu, G.; Kachroo, A. Enhanced disease susceptibility1 mediates pathogen resistance and virulence function of a bacterial effector in soybean. Plant Physiol. 2014, 165, 1269-1284. [CrossRef]

92. Eulgem, T.; Somssich, I.E. Networks of WRKY transcription factors in defense signaling. Curr. Opin. Plant Biol. 2007, 10, 366-371. [CrossRef]

93. Pandey, S.P.; Roccaro, M.; Schön, M.; Logemann, E.; Somssich, I.E. Transcriptional reprogramming regulated by WRKY18 and WRKY40 facilitates powdery mildew infection of Arabidopsis. Plant J. 2010, 64, 912-923. [CrossRef] [PubMed]

94. Robatzek, S.; Somssich, I.E. Targets of AtWRKY6 regulation during plant senescence and pathogen defense. Genes Dev. 2002, 16, 1139-1149. [CrossRef] [PubMed]

95. Choi, C.; Hwang, S.H.; Fang, I.R.; Kwon, S.I.; Park, S.R.; Ahn, I.; Kim, J.B.; Hwang, D.J. Molecular characterization of Oryza sativa WRKY 6, which binds to W-box-like element 1 of the Oryza sativa pathogenesis-related (PR) 10a promoter and confers reduced susceptibility to pathogens. New Phytol. 2015, 208, 846-859. [CrossRef] [PubMed]

96. Suh, S.J.; Bowman, B.C.; Jeong, N.; Yang, K.; Kastl, C.; Tolin, S.A.; Maroof, M.; Jeong, S.-C. The Rsv3 locus conferring resistance to soybean mosaic virus is associated with a cluster of coiled-coil nucleotide-binding leucine-rich repeat genes. Plant Genome 2011, 4, 55-64. [CrossRef]

97. Tran, P.-T.; Widyasari, K.; Seo, J.-K.; Kim, K.-H. Isolation and validation of a candidate Rsv3 gene from a soybean genotype that confers strain-specific resistance to soybean mosaic virus. Virology 2018, 513, 153-159. [CrossRef] [PubMed]

98. Gunduz, I. Genetic Analysis of Soybean Mosaic Virus Resistance in Soybean; Virginia Tech: Blacksburg, VA, USA, 2000.

99. Jeong, S.; Kristipati, S.; Hayes, A.; Maughan, P.; Noffsinger, S.; Gunduz, I.; Buss, G.; Maroof, M. Genetic and sequence analysis of markers tightly linked to the soybean mosaic virus resistance gene, Rsv 3. Crop Sci. 2002, 42, 265-270. [CrossRef] [PubMed]

100. Seo, J.-K.; Kwon, S.-J.; Cho, W.K.; Choi, H.-S.; Kim, K.-H. Type 2C protein phosphatase is a key regulator of antiviral extreme resistance limiting virus spread. Sci. Rep. 2014, 4, 5905. [CrossRef]

101. Hayes, A.J.; Ma, G.; Buss, G.R.; Maroof, M. Molecular marker mapping of Rsv 4, a gene conferring resistance to all known strains of soybean mosaic virus. Crop Sci. 2000, 40, 1434-1437. [CrossRef]

102. Maroof, M.; Tucker, D.M.; Skoneczka, J.A.; Bowman, B.C.; Tripathy, S.; Tolin, S.A. Fine mapping and candidate gene discovery of the soybean mosaic virus resistance gene, Rsv4. Plant Genome 2010, 3, 14-22. [CrossRef] 
103. Gunduz, I.; Buss, G.R.; Chen, P.; Tolin, S.A. Genetic and phenotypic analysis of Soybean mosaic virus resistance in PI 88788 soybean. Phytopathology 2004, 94, 687-692. [CrossRef]

104. Wang, Y.; Khatabi, B.; Hajimorad, M. Amino acid substitution in P 3 of S oybean mosaic virus to convert avirulence to virulence on R sv4-genotype soybean is influenced by the genetic composition of P 3. Mol. Plant Pathol. 2015, 16, 301-307. [CrossRef] [PubMed]

105. Klepadlo, M.; Chen, P.; Shi, A.; Mason, R.E.; Korth, K.L.; Srivastava, V.; Wu, C. Two tightly linked genes for Soybean mosaic virus resistance in soybean. Crop Sci. 2017, 57, 1844-1853. [CrossRef]

106. Zheng, C.; Chen, P.; Gergerich, R. Characterization of resistance to Soybean mosaic virus in diverse soybean germplasm. Crop Sci. 2005, 45, 2503-2509. [CrossRef]

107. Shi, A.; Chen, P.; Zheng, C.; Hou, A.; Zhang, B. A PCR-based marker for the Rsv1 locus conferring resistance to soybean mosaic virus. Crop Sci. 2008, 48, 262-268. [CrossRef]

108. Zheng, C.; Chen, P.; Li, D.; Gergerich, R. New sources of resistance to Soybean mosaic virus in soybean. Can. J. Plant Pathol. 2008, 30, 595-603. [CrossRef]

109. Buss, G.; Ma, G.; Chen, P.; Tolin, S. Registration of V94-5152 soybean germplasm resistant to soybean mosaic potyvirus. Crop Sci. 1997, 37, 1987-1988. [CrossRef]

110. Ma, G.; Chen, P.; Buss, G.; Tolin, S. Genetic characteristics of two genes for resistance to soybean mosaic virus in PI486355 soybean. Theor. Appl. Genet. 1995, 91, 907-914. [CrossRef]

111. Ilut, D.C.; Lipka, A.E.; Jeong, N.; Bae, D.N.; Kim, D.H.; Kim, J.H.; Redekar, N.; Yang, K.; Park, W.; Kang, S.-T.; et al. Identification of haplotypes at the Rsv4 genomic region in soybean associated with durable resistance to soybean mosaic virus. Theor. Appl. Genet. 2016, 129, 453-468. [CrossRef]

112. Fu, S.; Zhan, Y.; Zhi, H.; Gai, J.; Yu, D. Mapping of SMV resistance gene Rsc-7 by SSR markers in soybean. Genetica 2006, 128, 63-69. [CrossRef]

113. Yan, H.; Wang, H.; Cheng, H.; Hu, Z.; Chu, S.; Zhang, G.; Yu, D. Detection and fine-mapping of SC7 resistance genes via linkage and association analysis in soybean. J. Integr. Plant Biol. 2015, 57, 722-729. [CrossRef]

114. Zhao, L.; Wang, D.; Zhang, H.; Shen, Y.; Yang, Y.; Li, K.; Wang, L.; Yang, Y.; Zhi, H. Fine mapping of the RSC8 locus and expression analysis of candidate SMV resistance genes in soybean. Plant Breed. 2016, 135, 701-706. [CrossRef]

115. Ma, Y.; Li, H.; Wang, D.; Liu, N.; Zhi, H. Molecular mapping and marker assisted selection of soybean mosaic virus resistance gene RSC12 in soybean. Legume Genomics Genet. 2010, 1. [CrossRef]

116. Li, C.; Adhimoolam, K.; Yuan, Y.; Yin, J.; Ren, R.; Yang, Y.; Zhi, H. Identification of candidate genes for resistance to Soybean mosaic virus strain SC3 by using fine mapping and transcriptome analyses. Crop Pasture Sci. 2017, 68, 156-166. [CrossRef]

117. Zheng, G.-J.; Yang, Y.-Q.; Ying, M.; Yang, X.-F.; Chen, S.-Y.; Rui, R.; Wang, D.-G.; Yang, Z.-L.; Zhi, H.-J. Fine mapping and candidate gene analysis of resistance gene RSC3Q to soybean mosaic virus in Qihuang 1. J. Integr. Agric. 2014, 13, 2608-2615. [CrossRef]

118. Li, H.C.; Zhi, H.J.; Gai, J.Y.; Guo, D.Q.; Wang, Y.W.; Li, K.; Bai, L.; Yang, H. Inheritance and gene mapping of resistance to soybean mosaic virus strain SC14 in soybean. J. Integr. Plant Biol. 2006, 48, 1466-1472. [CrossRef]

119. Ma, Y.; Wang, D.-G.; Li, H.-C.; Zheng, G.-J.; Yang, Y.-Q.; Li, H.-W.; Zhi, H.-J. Fine mapping of the R SC14Q locus for resistance to soybean mosaic virus in soybean. Euphytica 2011, 181, 127-135. [CrossRef]

120. Li, K.; Ren, R.; Adhimoolam, K.; Gao, L.; Yuan, Y.; Liu, Z.; Zhong, Y.; Zhi, H. Genetic analysis and identification of two soybean mosaic virus resistance genes in soybean [Glycine max (L.) Merr]. Plant Breed. 2015, 134, 684-695. [CrossRef]

121. Li, N.; Yin, J.L.; Li, C.; Wang, D.G.; Yang, Y.Q.; Karthikeyan, A.; Luan, H.X.; Zhi, H.J. NB-LRR gene family required for Rsc4-mediated resistance to Soybean mosaic virus. Crop Pasture Sci. 2016, 67, 541-552. [CrossRef]

122. Ichimura, K.; Shinozaki, K.; Tena, G.; Sheen, J.; Henry, Y.; Champion, A.; Kreis, M.; Zhang, S.; Hirt, H.; Wilson, C.; et al. Mitogen-activated protein kinase cascades in plants: A new nomenclature. Trends Plant Sci. 2002, 7, 301-308.

123. Liu, J.-Z.; Horstman, H.D.; Braun, E.; Graham, M.A.; Zhang, C.; Navarre, D.; Qiu, W.-L.; Lee, Y.; Nettleton, D.; Hill, J.H.; et al. Soybean homologs of MPK4 negatively regulate defense responses and positively regulate growth and development. Plant Physiol. 2011, 157, 1363-1378. [CrossRef]

124. Liu, J.-Z.; Braun, E.; Qiu, W.-L.; Shi, Y.-F.; Marcelino-Guimarães, F.C.; Navarre, D.; Hill, J.H.; Whitham, S.A. Positive and negative roles for soybean MPK6 in regulating defense responses. Mol. Plant-Microbe Interact. 2014, 27, 824-834. [CrossRef] [PubMed] 
125. Kontra, L.; Csorba, T.; Tavazza, M.; Lucioli, A.; Tavazza, R.; Moxon, S.; Tisza, V.; Medzihradszky, A.; Turina, M.; Burgyán, J.; et al. Distinct effects of p19 RNA silencing suppressor on small RNA mediated pathways in plants. PLoS Pathog. 2016, 12, e1005935. [CrossRef] [PubMed]

126. Sharma, N.; Sahu, P.P.; Puranik, S.; Prasad, M. Recent advances in plant-virus interaction with emphasis on small interfering RNAs (siRNAs). Mol. Biotechnol. 2013, 55, 63-77. [CrossRef] [PubMed]

127. Li, M.L.; Weng, K.F.; Shih, S.R.; Brewer, G. The evolving world of small RNAs from RNA viruses. Wiley Interdiscip. Rev. RNA 2016, 7, 575-588. [CrossRef]

128. Alazem, M.; Kim, K.H.; Lin, N.S. Effects of Abscisic Acid and Salicylic Acid on Gene Expression in the Antiviral RNA Silencing Pathway in Arabidopsis. Int. J. Mol. Sci. 2019, 20, 2538. [CrossRef]

129. Park, J.H.; Shin, C. The role of plant small RNAs in NB-LRR regulation. Brief. Funct. Genomics 2015, 14, 268-274. [CrossRef]

130. Li, F.; Pignatta, D.; Bendix, C.; Brunkard, J.O.; Cohn, M.M.; Tung, J.; Sun, H.; Kumar, P.; Baker, B. MicroRNA regulation of plant innate immune receptors. Proc. Natl. Acad. Sci. USA 2012, 109, 1790-1795. [CrossRef]

131. Mallory, A.C.; Hinze, A.; Tucker, M.R.; Bouché, N.; Gasciolli, V.; Elmayan, T.; Lauressergues, D.; Jauvion, V.; Vaucheret, H.; Laux, T. Redundant and specific roles of the ARGONAUTE proteins AGO1 and ZLL in development and small RNA-directed gene silencing. PLoS Genet. 2009, 5, e1000646. [CrossRef]

132. Planas-Riverola, A.; Gupta, A.; Betegón-Putze, I.; Bosch, N.; Ibañes, M.; Caño-Delgado, A.I. Brassinosteroid signaling in plant development and adaptation to stress. Development 2019, 146, dev151894. [CrossRef]

133. Sarma, B.K.; Singh, H.B.; Fernando, D.; Silva, R.N.; Gupta, V.K. Enhancing plant disease resistance without R genes. Trends Biotechnol. 2016, 34, 523-525. [CrossRef]

134. Gao, L.; Luo, J.; Ding, X.; Wang, T.; Hu, T.; Song, P.; Zhai, R.; Zhang, H.; Zhang, K.; Li, K. Soybean RNA interference lines silenced for eIF4E show broad potyvirus resistance. Mol. Plant Pathol. 2019. [CrossRef] [PubMed]

135. Bastet, A.; Robaglia, C.; Gallois, J.-L. eIF4E resistance: Natural variation should guide gene editing. Trends Plant Sci. 2017, 22, 411-419. [CrossRef]

136. Zhou, L.; He, H.; Liu, R.; Han, Q.; Shou, H.; Liu, B. Overexpression of GmAKT2 potassium channel enhances resistance to soybean mosaic virus. BMC Plant Biol. 2014, 14, 154. [CrossRef] [PubMed]

137. Yang, X.; Niu, L.; Zhang, W.; Yang, J.; Xing, G.; He, H.; Guo, D.; Du, Q.; Qian, X.; Yao, Y. RNAi-mediated SMV P3 cistron silencing confers significantly enhanced resistance to multiple Potyvirus strains and isolates in transgenic soybean. Plant Cell Rep. 2018, 37, 103-114. [CrossRef] [PubMed]

138. Furutani, N.; Hidaka, S.; Kosaka, Y.; Shizukawa, Y.; Kanematsu, S. Coat protein gene-mediated resistance to soybean mosaic virus in transgenic soybean. Breed. Sci. 2006, 56, 119-124. [CrossRef]

139. Kim, H.J.; Kim, M.-J.; Pak, J.H.; Jung, H.W.; Choi, H.K.; Lee, Y.-H.; Baek, I.-Y.; Ko, J.-M.; Jeong, S.-C.; Pack, I.S.; et al. Characterization of SMV resistance of soybean produced by genetic transformation of SMV-CP gene in RNAi. Plant Biotechnol. Rep. 2013, 7, 425-433. [CrossRef]

140. Gao, L.; Ding, X.; Li, K.; Liao, W.; Zhong, Y.; Ren, R.; Liu, Z.; Adhimoolam, K.; Zhi, H. Characterization of Soybean mosaic virus resistance derived from inverted repeat-SMV-HC-Pro genes in multiple soybean cultivars. Theor. Appl. Genet. 2015, 128, 1489-1505. [CrossRef]

141. Redekar, N.; Clevinger, E.; Laskar, M.; Biyashev, R.; Ashfield, T.; Jensen, R.V.; Jeong, S.-C.; Tolin, S.; Maroof, S. Candidate gene sequence analyses toward identifying Rsv3-type resistance to Soybean mosaic virus. Plant Genome 2016, 9. [CrossRef]

142. Chandrasekaran, J.; Brumin, M.; Wolf, D.; Leibman, D.; Klap, C.; Pearlsman, M.; Sherman, A.; Arazi, T.; Gal-On, A. Development of broad virus resistance in non-transgenic cucumber using CRISPR/Cas9 technology. Mol. Plant Pathol. 2016, 17, 1140-1153. [CrossRef]

143. Kim, H.J.; Kim, M.-J.; Pak, J.H.; Im, H.H.; Lee, D.H.; Kim, K.-H.; Lee, J.-H.; Kim, D.-H.; Choi, H.K.; Jung, H.W.; et al. RNAi-Mediated Soybean Mosaic Virus (SMV) Resistance of a Korean Soybean Cultivar; Springer: Berlin/Heidelberg, Germany, 2016.

(C) 2020 by the authors. Licensee MDPI, Basel, Switzerland. This article is an open access article distributed under the terms and conditions of the Creative Commons Attribution (CC BY) license (http://creativecommons.org/licenses/by/4.0/). 